\title{
Introduction
}

\author{
PROTESTING “PROTECTIVE EDGE,” CHICAGO, \\ JULY 26, 2014
}

In July 2014, as I was finishing the research in Chicago for this book, Israel bombarded the Gaza Strip in yet another attempt-the third since 2008-to destroy the military and governing capacities of the Islamic Resistance Movement, known commonly as Hamas. Labeled "Operation Protective Edge," the attack, which killed more than 2,00o civilians and injured an additional 11,00o, sparked global condemnation, including a massive public response from Chicago's Palestinians (Dearden 2014; Waldroup 2014). In a well-rehearsed procedure-this was not the first time they had mobilized-the Chicago Coalition for Justice in Palestine, an ad hoc group comprising the city's major organizations active on the Palestinian cause, called for a demonstration in the Loop, Chicago's downtown area. Dramatizing their dominant role in the community, the mosques bussed hundreds of their constituents from the southwest suburbs. Event organizers claimed 15,000 demonstrators; the local NBC affiliate put the figure at 8,000 (Waldroup 2014).

Slogans at the rally and during the subsequent march down Michigan Avenue demanded "free Palestine" and declared "God is greater." The traditional flag featuring a plain triangle of red and three bars each of black, white, and green mingled with other versions of the national banner. ${ }^{1}$ There were two Islamized variations. The first inscribed the shahada declaration (creedal statement) of la ilaha illa llah/ muhammadun rasulu llah-"There is no deity save the one God/Muhammad is God's messenger" - on the white middle field of the banner (Figure 1).²

The second superimposed an image of the Dome of the Rock-the site from which, according to tradition, Muhammad ascended through the heavens to the throne of God-and the words "filastin kulluha qudsun" (Figure 2). The words, which translate as "Palestine, All of It [is] Sanctified [or, Sacred, Holy]," played on the traditional name for Jerusalem in Arabic, "al-Quds," the Sanctified (Sacred, Holy). Both flags appeared alongside the US flag. The juxtaposition signaled a specifically Palestinian claim to American political citizenship and national affiliation. 


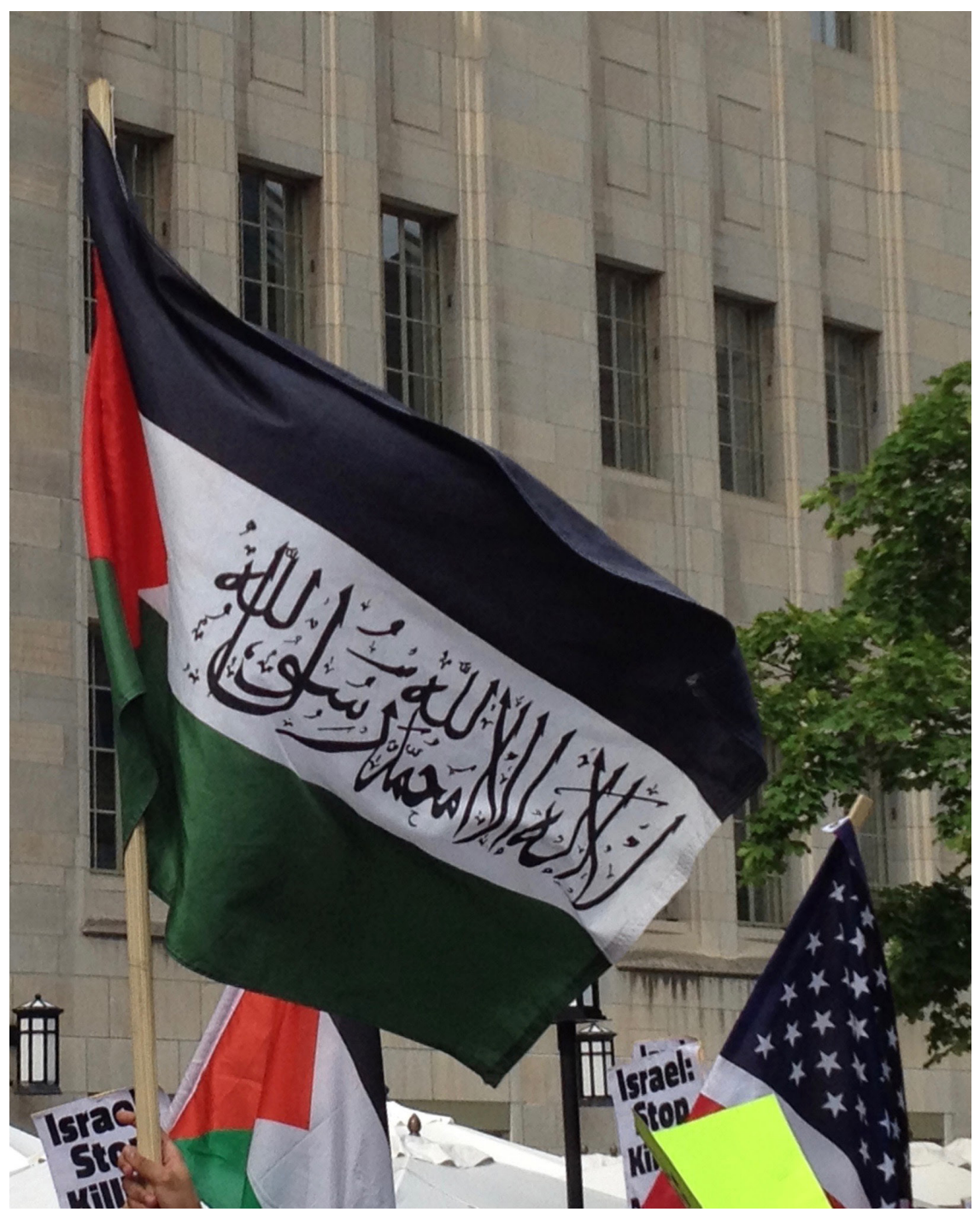

FIGURE 1. Palestinian flags, traditional and Islamized, alongside US flag.

Religious and nationalist symbolic displays also appeared in the clothing choices of some women demonstrators. Women wearing hijab scarves in a checkered black-and-white kufiya (colloq: kaffiyeh or hatta) design or in the colors of the Palestinian national flag walked alongside women wearing kufiya-patterned scarves around their necks but nothing on their heads (Figure 3).

Signs and chants at the demonstration demanded "Israel: stop killing" and decried the attack on Gaza as "genocide." They also called for boycott, divestment, 


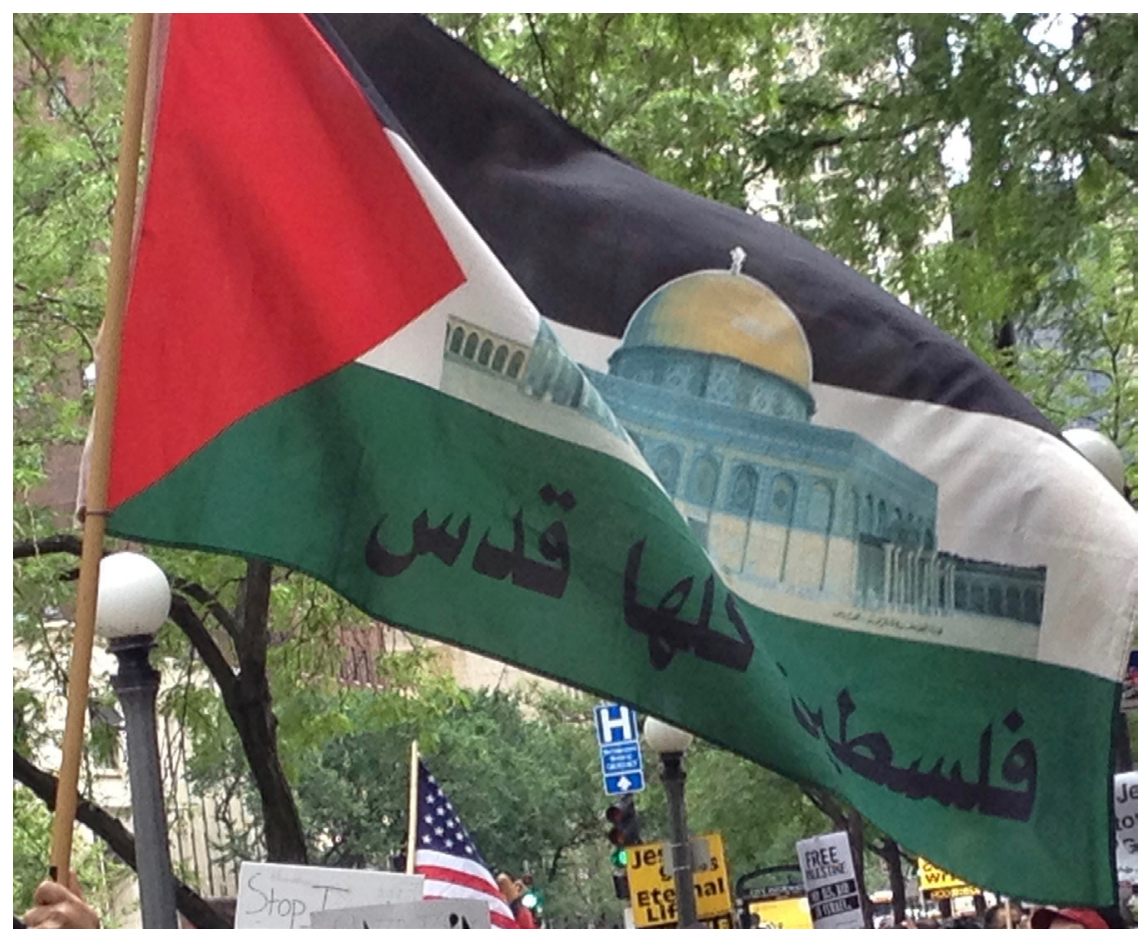

FIGURE 2. Palestinian flag featuring a stencil of the Dome of the Rock; US flag in background.

and sanctions against Israel's "apartheid" and for ending US financial support for the Jewish state ("Not another nickel, not another dime for Israel's crime!") Other slogans revived the assertion-which the Palestine Liberation Organization (PLO) had effectively abandoned in its acceptance of the two-state principle ${ }^{3}$ - "from the [Jordanian] River to the [Mediterranean] Sea/Palestine will be free!"

Organizers and protestors who gave interviews to NBC also presented a united front across secular, religious, and ethnic lines. Kristin Szremski, a convert to Islam and, at the time, a staff member in charge of media relations for American Muslims for Palestine (AMP), which receives detailed analysis in chapter 3, appeared on camera in hijab, declaring: "I believe Israel needs to end the occupation. Period. And that's how we're going to achieve peace" (Waldroup 2014). Executive Director of the Arab American Action Network Hatem Abudayyeh, who is profiled in the analysis of secularism in chapter 2, echoed Szremski: "The Palestinian people want peace. Absolutely. We always have. But, peace with justice” (Waldroup 2014). Deena Kishawi, a college student and protester wearing a red hijab and black-and-white kufiya kerchief under her scarf, also emphasized the theme of protecting civilian lives and overturning Israel's decades-long control of the Occupied Territories: "My message to Israel and to everybody out there is to stop killing Palestinians, to end the siege, to end the occupation" (Waldroup 2014). Finally, Lynn Pollack of the 


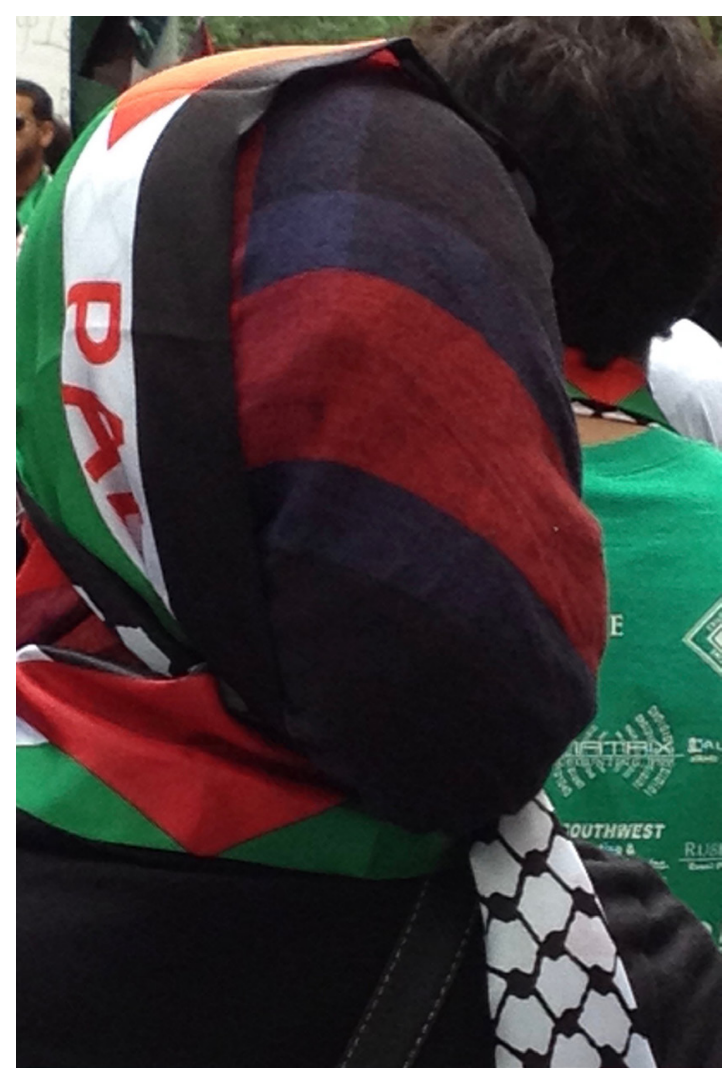

FIGURE 3. Demonstrator wearing the national colors and kufiya scarf over hijab.

anti-Zionist Jewish Voice for Peace solidarity group appealed to her fellow Jewish Americans "to stand up and take a good look at what is happening and say you don't want it done in your name either" (Waldroup 2014).

Religious and secular symbols appeared to blend seamlessly in this mass demonstration against Israel's violence. The secular, in the sense of the priority given to the crisis and question of Palestine, had seemingly assimilated Islamic signifiers as part of a nonsectarian space that included Jewish solidarity groups. But Islam, too, had embraced the nation, centering its cause as an article of faith: devotion to the One God entailed devotion to the liberation of the national patrimony, which God had made sacred. The inverse relation also seemed to hold: commitment to the nation required affirmation, at least strategically, of Islam's central importance. This religious-secular synthesis appeared an accomplished fact in 2014. Nevertheless, behind the integrated display lay a longer history of tension and shift. 


\section{THE PROJECT}

This book documents and analyzes the history of this shift and its present-day impact in one of the world's most important Palestinian diaspora communities, Palestinian Chicago. At approximately 85,000 strong, this community constitutes the single largest concentration of Palestinians in North America. ${ }^{4}$ Their sheer size has made them a target of scrutiny. Chicago's main newspaper, the Chicago Tribune, has periodically published exposés claiming to have uncovered connections to radical Islamic and leftist groups that the US government has listed as "foreign terrorist organizations." And, since the 1970s, the Federal Bureau of Investigation and Department of Justice have launched probes against activists suspected of supporting proscribed movements (Ahmed-Ullah, et al. 2004; Ahmed-Ullah, Roe, and Cohen 2004; Cainkar 2009, 110-52). Chicago's Palestinians have, as a consequence, become linked directly to the putative Global War on Terror; and, in response, they have fought back against interventions made against them. Since the election of President Donald J. Trump, for example, activists in the community have led protests against the "Muslim Ban," the final version of which severely limits travel to the United States from five Muslim-majority countries (Iran, Libya, Syria, Yemen, and Somalia) as well as from North Korea and Venezuela.

The analysis I present of this community in this book rests on my decades-long interaction with its members and leaders and with the situation in Palestine itself. My first encounter with Palestinian communities and the national struggle that has so powerfully defined their collective sense of identity came during a threeyear stint as a volunteer English teacher in the West Bank (1986-89). The First Intifada - the mass Palestinian uprising against the Israeli occupation (1987-93) erupted during this time. The event profoundly affected me. Several of my students were arrested in demonstrations as part of the sweeping imprisonments of leaders and youth activists, and some were severely injured. A friend was shot and killed at close range while being questioned at a military checkpoint in the town of Beit Jala. Following the military's closure of all schools in early 1988, I began work with the Palestinian Human Rights Information Center (PHRC) in East Jerusalem. I assisted PHRC's fieldworkers in collecting data on Israeli military violence in Palestinian communities across the West Bank and Gaza Strip.

In 1989, I left the West Bank to complete a master's degree in Applied Linguistics at the American University in Cairo. The first Gulf War occurred during this interval. Israel imposed a complete blockade and curfew of the Occupied Territories. After the war, in 1991, I accepted a job as an English teacher in the Gaza Strip (1991-93). The Intifada was imploding. The Gulf War had severely weakened the PLO, which had sided diplomatically with Iraq. Israel's extended closures and violent repression during the war had exhausted the population. And the relationship between Hamas and Fatah, the PLO's predominant faction, had become embittered and violent. 
I left Gaza in 1993 to pursue graduate studies in religion and sociology. My dissertation project involved a full year of fieldwork in Palestine, 1999-2000. This research, occurring just before the outbreak of the Second (al-Aqsa) Intifada, became the foundation for several publications, including my first book, on the transformation of Palestinian identity in response to the deepening Islamistsecular-nationalist fracture (Lybarger 2005; 2007a; 2007b; and 2013).

While pursuing my studies in Chicago, I developed ties with the city's Palestinian immigrant community. Activist friends, some of whom I had met in the West Bank, introduced me to leaders at the Arab Community Center, known simply as "the markaz (center)." The markaz had been an anchor of the Southwest Side immigrant enclave since the early 1970s. It had a pronounced secular-left, pan-Arab, and Palestinian nationalist orientation. The center provided a range of community services, including language training, after-school cultural activities, and social work assistance. I volunteered as an English teacher for a brief period and occasionally attended organizing meetings at the markaz through the mid1990 s and early 200os. I began to notice during my visits to the center that younger staff members and youth program participants were increasingly embracing outward markers of Islamic piety (beards, brimless knitted kufi caps, hijab scarves). This phenomenon was remarkable given the markaz's secularist ethos.

The most striking manifestation of this change occurred at a fundraising dinner I attended for the Arab American Action Network (AAAN) in 1998. The AAAN was a new social service organization that replaced the Arab Community Center. The late Edward Said-the renowned Columbia University scholar and foremost Palestinian public intellectual in the United States-had come from New York to keynote the event. With dinner concluding, Said prepared to speak. Suddenly, there was a commotion. Tens of university students in the audience had risen and were forming ranks to perform the maghrib (dusk) prayer toward the side of the banquet space. One of the students, a young bearded man in a kufi cap, began intoning the adhan (call to prayer) in a resonant baritone.

As the prayer proceeded, Said waited at the podium while those who had remained in their seats shifted uncomfortably and exchanged indignant comments. The fundraiser was a secular, nonsectarian event meant to raise money for a secular, nonsectarian organization. The audience comprised Muslims as well as Christians, Jews, and many individuals who identified as secular. The unexpected intervention of the prayer-it had not been included in the program-palpably transformed the mood, producing confusion and tension.

The memory of this dramatic disruption of the AAAN fundraiser, and the interruption of Edward Said, a staunch defender of both the Palestinian cause and of secularism, ${ }^{5}$ remained with me long after the incident. I returned to that moment frequently through the years whenever I spoke with my markaz friends in Chicago about the religious shift that had occurred. By the 2000 , the shift had 
expanded substantially as the community transitioned to the suburbs. The secular community centers had closed while the mosques, situated in the new enclave, flourished. ${ }^{6}$ The AAAN, which had established itself in the old markaz premises in the Southwest Side Chicago Lawn area, was an exception to the trend. It nevertheless had accommodated the religious shift, too, in various ways (as explored in chapters 2 and 5 and elsewhere). The shift was broad and undeniable. Why this change had happened and what its impact had been became central questions for me in those early conversations. They eventually became the focus of this book.

\section{QUESTIONS AND DATA}

Four main questions orient this project. First, what historical, social, and political factors have shaped Palestinian identities in Chicago? How, specifically, did secular nationalism and religion-principally Islam in various forms but also Christianity-become primary identity frameworks at individual and community levels? Second, what explains the ascendancy of Islam, in particular, since the 1990s, and what has happened to secularism in relation to this process? Third, what forms of identity have emerged through the ensuing intersections of the religious and the secular in Palestinian Chicago? Finally, what critical perspectives does this case study provide for understanding Palestinian identity in diaspora contexts in the current moment?

I answer these questions through the description and analysis of fieldwork data. These data derive from summer research trips to Chicago occurring between 2010 and 2013 and from a two-year research residency in the city from 2013-15. The data include multiple site observations at mosques, churches, community centers, downtown protests, and community events as well as more than eighty recorded life-story interviews. Each of the interviews lasted two or more hours and in some cases included extended follow-up conversations. ${ }^{7}$ Analysis of the data has entailed identification and interpretation of themes within and across the transcribed interviews and my field notes.

\section{MAIN ASSERTIONS}

I make several interrelated assertions about what these fieldwork data show. My first claim is that the religious turn in Chicago results from a complex interaction of homeland and diaspora-specific processes. The primary homeland factor is the development, since the late $198 \mathrm{os}$, of powerful Islamist competitors to the secularnationalist Palestine Liberation Organization. These movements, principally the Muslim Brotherhood and its successor, Hamas, have split Palestinian society into competing secular nationalist and Islamist spheres. The division has manifested geographically: since 2007, Hamas has dominated the Gaza Strip while the secular 
nationalist Fatah movement, the largest of the PLO factions, remains in nominal control of parts of the West Bank. I show how the Islamic shift, in its broad sense, in Palestine and in the wider Middle East has influenced the religious turn in Chicago through family networks spanning the United States and Palestine. But the book also demonstrates the impact of other factors specific to the Palestinian experience in Chicago. These factors include the development of religious institutional structures as part of an ongoing selective assimilation process; the shuttering of secular nationalist community centers; wealth accumulation and the demographic transition to a new suburban enclave; and the anti-Muslim backlash in the long aftermath of the September 11, 2001 attacks.

My second main assertion is that the religious shift and the tensions it produces with secularism have generated a range of hybrid identities in the present. These identities defy simplistic narratives about the "Islamization" of immigrant communities or about the "decline" of secularism in the face of a global religious resurgence. This finding pushes back against prevailing scholarship on these matters. This scholarship is of two sorts. The first has tended to raise alarm about the effect of Muslim immigration on Western democracy and secular culture (Brookes and Sciolino 1995; Levitt 2006; Roy 2007; Amghar, Boubekeur, and Emerson, 2007; Sniderman and Hagendoorn 2007; Nasaw 2008; Westrop 2017). The second has focused positively on the formation of a Western umma (Islamic community), internally dynamic and contested, auguring a new, transcultural Western Islam (Ramadan 2004; Karim 2009; Grewal 2014; Khabeer 2016). This contradictory discussion parallels a public discourse in which racist and xenophobic portrayals of Muslim immigrants vie with counterclaims about Islam being a religion of peace compatible with a secular democratic order.

Obscured in these contending discourses is the complexity of secular-religious dynamics in the actual lives of individuals and communities. I call attention to this fact, showing how the religious turn has had multiple effects in Palestinian Chicago. As I show, secularism has not disappeared but rather transmuted, taking new forms in interaction with the religious turn. Similarly, the new religious orientations bear the imprint of secularism and in doing so develop in multiple indeterminate directions. Significantly, these transformations have analogs in the experience of Palestinian Christians, whom I also highlight in the chapters ahead. Adding to the complexities of these secular-religious interactions is the impact of a range of other mitigating factors, especially race, class, gender, generation, and space. This book analyzes these factors, showing how they shape the religioussecular dynamics in the narrative accounts of my interlocutors.

My third set of arguments pertains to the broader implications of my findings for Palestinians and non-Palestinian others in the current moment. I make two observations. First, Palestinian identity in the diaspora is likely to continue to develop in multiple directions as the religious shift deepens and as that same shift 
generates secular-religious hybrid responses. Second, the experiences of Palestinians in Chicago shed light on secular-religious tensions and transformations that manifest in diverse societies globally. These Palestinian accounts contribute empirical depth to arguments that Taylor (2007), Martin (2014), and Riesebrodt (2014), among others, have separately made about how the religious and the secular enter into a mutually "fragilizing" relation, each destabilizing but also conditioning the other in a dialectic that produces new syntheses. The Palestinian voices that register in this book provide crucial insight into these processes and into the possibilities they create for forging new, contrapuntal conceptions of self and other across multiple lines of difference, including the religious and the secular.

\section{CONTEXTUALIZING THE RELIGIOUS SHIFT}

\section{Secularist and Islamist Formations in Palestine}

My assertions above reflect a historical context in which secular nationalism and Islamism constitute contending responses among Palestinians to the experience of dispossession. The central defining feature of the secularist response has been its emphasis on the ethnos - the specifically Palestinian Arab nation-and its collective search for statehood. Secularism in this sense emphasizes a common identity rooted in a shared language (Arabic) and shared customs and traditions (the 'adat wa taqalid that structured traditional village life). It also roots itself in a narrative of catastrophic loss and heroic revolution (thawra) flowing from successive traumas. These traumas include, principally, the wars of 1948 and 1967 but also refer to later events like the Israeli invasion of Lebanon in 1982, which resulted in the deaths of close to 20,000 Lebanese and Palestinians, 90 percent of them civilians, and in the PLO's expulsion from Beirut (Chomsky 1999 [1983], 388); the First Intifada (1987-93); and the Second Intifada (2000-05). At the heart of Palestinian secular nationalism, historically, however, is the claim to an ancestral territory according with the boundaries of the former British Mandate for Palestine (1922-48) (Figure 4).

In addition to emphasizing the ethnos and its territorially bounded space-a feature of modern nationalisms-Palestinian secularism has historically affirmed religious identities as part of the cultural mosaic and heritage of the Palestinian people. This affirmation has included the important caveat that no single religion retains a privileged position. In its Marxist forms, Palestinian secularism has at times rejected religion outright as "false consciousness" and an obstacle to national and human liberation; but the form of secularism that has predominated among Palestinians has emphasized multisectarian unity under a common identification with the nation and its cause of liberation. The core organizational structures of this form of secularism remain the various factions that constitute the PLO. Principal among these factions have been the Palestinian National Liberation Movement (Fatah/harakat al-tahrir al-watani al-filastini), and the Movement of 


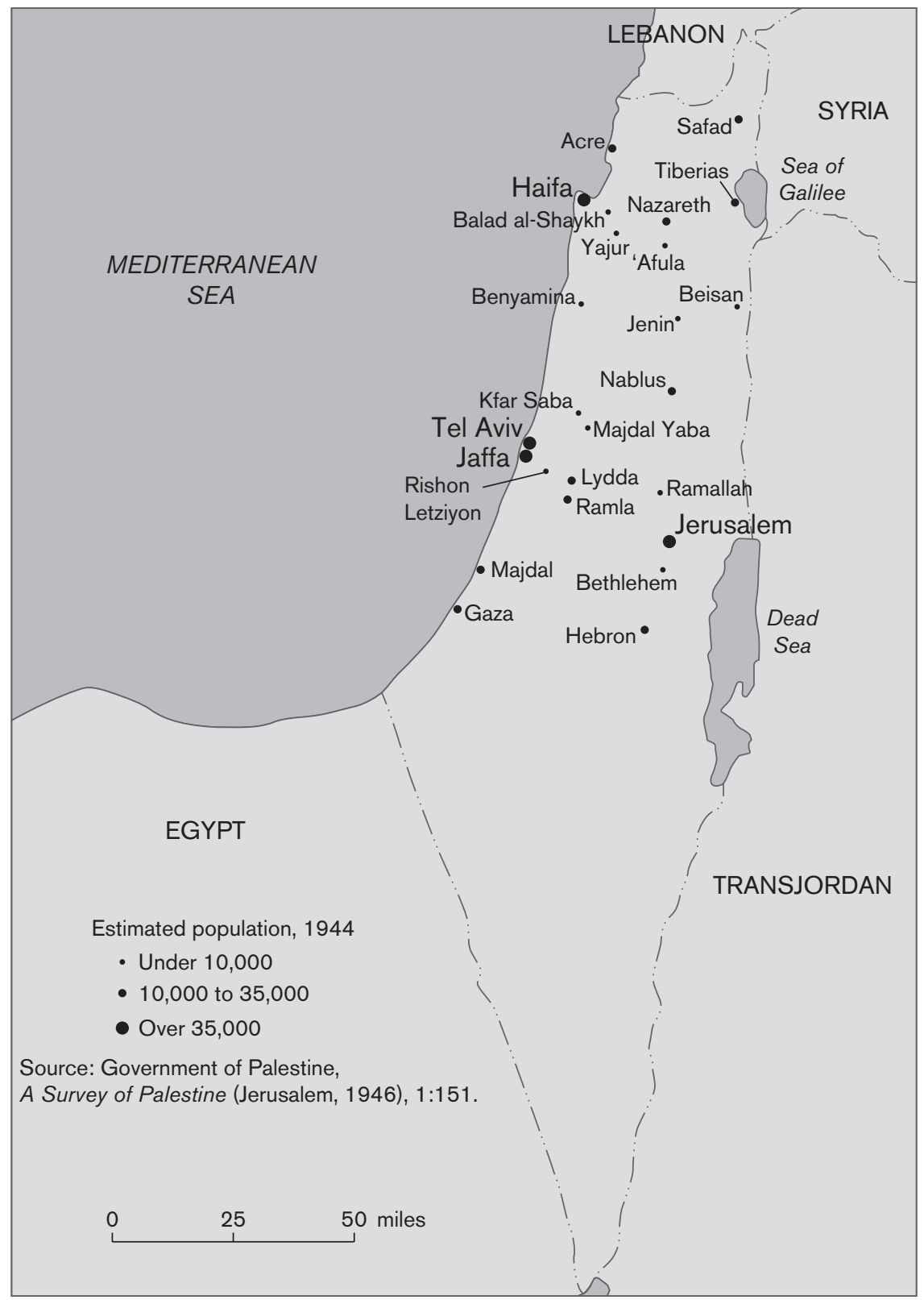

FIGURE 4. Map of British Mandate for Palestine, 1922-1948. Source: A Survey of Palestine, Vol. 1 (Washington, DC: Institute for Palestine Studies, 1991), 151. Used with permission of the Institute for Palestine Studies. 
Arab Nationalists (MAN/harakat al-qawmiyin al-arab), which, after the war of 1967, became the Marxist-Leninist-oriented Popular Front for the Liberation of Palestine.

These PLO factions first emerged during the 1950 s as Palestinians contended with their traumatic mass displacement and transformation into refugees following the war of 1948. In the aftermath of the war of 1967 , in which Israel occupied Arab East Jerusalem and the West Bank, Gaza Strip, Golan Heights, and Sinai Desert, the Fatah movement, in a dramatic move, took control of the PLO, transforming it into a Palestinian government in exile. With Nasser-led pan-Arabism in disarray, the phoenix-like rise of the Fatah-led PLO inspired Palestinian and Arab youth across the region to join the armed units of "the revolution" (althawra) in Jordan and, later, in Lebanon. The PLO quickly became the preeminent global tribune of the Palestinian cause: under the chairmanship of the late Yasser Arafat, it achieved the status of sole legitimate representative of the Palestinian people. Israel's invasion of Lebanon in 1982 destroyed the PLO's last independent base of operation, forcing the movement into a distant exile, first in Algeria and then in Tunisia. The First Intifada (1987-93) and subsequent Oslo Peace Process (1993-present), however, enabled Fatah, the PLO's dominant faction, to regain its position and prominence on the global stage. Ironically, the formation of the Fatah-controlled Palestinian National Authority as part of the subsequent Oslo process intensified the weakening of the PLO as a political structure for diaspora Palestinians. This weakening had already begun during the first Gulf War (1990-91), when Gulf countries cut financial support for the organization. One consequence of this process was the hollowing out of secular nationalist institutions in diaspora communities. In Chicago, the collapse of the secular nationalist community centers, which oriented politically to the various PLO factions and to the liberation programs they represented, signaled this new reality.

In contrast with Palestinian secularism, the orienting horizon of Palestinian Islamism has been the umma (the transcultural and transhistorical Islamic community) and its claim to sovereignty in Palestine. At the center of this claim is Jerusalem, the mythic site of the Prophet Muhammad's miraculous heavenly ascent (the mir raj). Palestine has long served as a symbolic focal point of Islamic revival and anti-colonial resistance. ${ }^{8}$ The Syrian pan-Islamist 'Izz al-Din al-Qassam, for example, whose preaching and organizing in the Galilee region helped lay ground for the Great Revolt (1936-39), thematized resistance to British domination and Zionist colonization in terms of Islamic solidarity and jihad. Hasan al-Banna, founder of the Egyptian Muslim Brotherhood in 1928, also preached extensively in towns and villages up and down the Nile River about the threat of Zionism as part of his call for a revival of Islam to counter British colonialism. The Muslim Brotherhood provided important backing for al-Hajj Amin al-Husayni, the Mufti of Jerusalem and leader of the Supreme Muslim Council in Palestine, the main 
organization leading the Palestinian national movement during the 1930s. The Brotherhood also sent guerrilla fighters to the Gaza Strip during the war of 1948, during which approximately 750,000 Palestinians were forcibly expelled from their towns and villages in what became Israel. Muslim support for Palestinian nationalism also extended beyond the Middle East. Leaders of the Indian Khalifat movement, for example, attended the World Islamic Congress, held at al-Aqsa Mosque under Husayni's auspices in 1931 (O. Khalidi 2009; Swedenberg 1995; Schleifer 1993; Mattar 1988; Brynjar 1988; Kupferschmidt 1987).

Since the 1980s, Hamas and Islamic Jihad have again centered Palestine within the discourse of global Islamic solidarity. They refer to "Muslim Palestine" and conceive the struggle through religious symbols and terms like al-jihad fi sabil illah ("armed struggle in the path or cause of God"). For these movements, the jihad for Palestine is the key to Islam's revival elsewhere. This idea mirrors Fatah and the PLO's insistence that Arab political renaissance depended on a prior commitment and solidarity among all Arabs to free Palestine through the armed struggle-in the secularist lexicon, al-kifah al-musallah ("the armed struggle"), not al-jihad $f i$ sabil illah (Gunning 2008; Mishal and Sela 2000; Hroub 2000; Nüsse 1998; MiltonEdwards 1996). Global movements like al-Qaeda have also invoked Palestine, but in doing so have reversed the causal logic of liberation: Palestinian freedom would come only after Muslims had united as Muslims to strike against the "far enemy" (the United States) (Euben and Zaman 2009; Gerges 2009 [2005]). The Islamic State movement has similarly predicated the liberating of the territories comprising Israel, the Gaza Strip, and the West Bank on the revival of Islamic solidarity, primarily through the resurrection of the historical caliphate under its leadership. The Islamic State disdains both the PLO and Hamas as anti-Islamic because of the primary focus of these groups on Palestinian national liberation rather than on conquest of a territorial base for a revived umma (Guardian 2015).

The Islamic State's critique of Hamas is not without foundation: since its creation, Hamas has sought, through its emphasis on jihad, to wrest the mantle of armed struggle on behalf of the nation from Fatah and the PLO. In 2007, Hamas forced Fatah out of the Gaza Strip in a brief but bloody civil war that split control of the Palestinian National Authority (PNA). Since then, Hamas has dominated PNA institutions in Gaza while Fatah has retained power in the semiautonomous zones in the West Bank. In its subsequent armed engagements with Israel-such as in the 2014 "Protective Edge" invasion described at the start of this chapter-Hamas has repeatedly asserted itself as the champion of Palestinian liberation. In doing so, it has sought to cast Fatah, which has remained committed to the moribund peace process, as corrupt and compromised. One unanticipated consequence of Hamas's ascendancy has been an incipient sectarianizing reaction among some Palestinian Christians. These Christians have responded to the Islamic reframing of Palestinian nationalism by redefining belonging narrowly in relation to 
Christian narratives and institutions (S. Roy 2011; Milton-Edwards and Farrell 2010; Lybarger 2007b).

\section{Secularism and Islam in the Diaspora: The Exilic Difference}

As the July 2014 demonstration in Chicago's downtown showed, and as my own observations during the 1990 also indicated, the diaspora has not been immune to the Islamic-secular competition and consequent realignments of solidarities that have arisen since Hamas's ascendancy. This phenomenon has received scant balanced attention. Journalism and scholarship on Islam, Islamic movements, Islamic revival, or Islamism in relation to Palestinians have focused primarily on Hamas or on its supposed outposts in diaspora centers like Chicago. ${ }^{9}$ The operating assumption of the latter set of discussions is that Arab and Muslim diasporas are merely extensions of homelands situated elsewhere. Yet, as diaspora studies scholarship has demonstrated, the diaspora-homeland relationship is fluid, with influences moving in both directions (Bernal 2014; Alonso and Oiarzabal 2010; Brinkerhoff 2009; Brubaker 2005; Appadurai 1991 and 1996; Clifford 1994; S. Hall 1990). Moreover, assimilation processes in immigrant communities transform collective identities, generating new trajectories across time (Gordon 1964; Bodnar 1985; Gans 1992; Portes and Zhou 1993; Alba and Nee 1997; Deaux 2006; Serhan 2009; Kivisto 2014). Religious retrieval and revival can occur, especially in situations of racist reaction (Kivisto 2014). But, even in such instances, the retrieval always occurs within the circumstances of the exile, which are distinct from those in the homeland. Indeed, where "home" is becomes the defining question of immigrant life, especially when the legitimacy of an immigrant group's presence is continually thrown into question.

Palestinian historical experience is no exception. The conditions of life in the Palestinian diaspora differ from those in Palestine itself even if diaspora and homeland remain intertwined because of travel, electronic communication, and the perpetuation of narratives of "return" ( $a l$-'awda). The assumption that the secular-Islamist split in Palestine-a highly complex phenomenon not easily reducible to this binary (Lybarger 2007a, 2007b, 2013) - directly shapes an analogous fracture in the diaspora can therefore mislead. Diaspora contexts generate their own predicaments and dynamics. Palestinians in these settings confront not only the crisis of the nation "back home" but also the question of belonging within the countries to which they have immigrated. This question of belonging evolves in complicated ways across space and time. As in Palestine, identities in diaspora contexts such as in Chicago have overlapped and hyphenated in a constant negotiation of place and space.

\section{Secularism and the Religious Turn in Palestinian Chicago}

Palestinian immigration to Chicago dates to the late 1890 o but began in earnest after the wars of 1948 and 1967. The period after these wars coincided with the rise of secular, multisectarian pan-Arab nationalism and specifically Palestinian 
liberation movements like Fatah. After the war of 1967, activists in Chicago and elsewhere in the United States created new community centers that aligned ideologically with the various factions of the reconstituted, Fatah-led PLO. The student movement also gained momentum through the activities of the Organization of Arab Students (OAS), established in 1952 at the University of Michigan; the General Union of Palestinian Students, formed in Cairo, Egypt, in 1959; and the Association of Arab American University Graduates (AAUG), founded in 1967. These structures proved instrumental to forging attachment to Palestinian national identity within and beyond immigrant enclaves during the 1970s and 1980s (Pennock 2017, 21-117).

During the 1990s, however, alongside the rise of Islamist politics in Palestine, a discernible shift toward Islam as a primary framework of solidarity occurred. Islamic organizations, such as the Muslim Brotherhood-aligned Muslim Student Association chapters (MSA), had established presences on university campuses since 1963. They openly rejected Arab and Palestinian nationalist activism, however, seeing it as "secular" and thus contrary to Islamic solidarity (Pennock 2017, 53)..$^{10}$ In the 1990s, in cities like Chicago, young activists identifying explicitly with Islam as a new global framework for mobilization within and beyond the Palestinian immigrant community came to the fore. The signs of this change were evident in new forms of dress, grooming, and comportment. These forms of attire marking the new piety had even become evident in spaces once considered secularist bastions. At the Arab Community Center, the markaz mentioned earlier, young activists led prayers in the corners of the main room, attracting the participation of youth enrolled in the organization's programs.

Signs of a revitalized Islamic identity within the wider immigrant community were also apparent during the 1990s. Cainkar (2004, 113-14) noted the appearance of halal meat markets, the closing of nationalist cultural centers, and the corresponding rising attendance at mosques and private Islamic schools run by those mosques. She also reported "personally observ[ing] hundreds of individuals change from secular to religious since the mid-199os, while conducting research and participating in the Arab and Muslim communities [in Chicago]" (114). Such developments signaled a broad shift within the ethos of the Palestinian immigrant community as a whole. At the largest Palestinian-dominated mosque, the Mosque Foundation in the southwest suburb of Bridgeview, attendance shot from an average of 75 attendees at Friday prayers in 1982, just after the mosque was built, to nearly 2,000 worshippers every week in 1994. Schmidt (2004), documenting the emergence of a generation of self-identified Muslim activists who were establishing and leading a range of new Islamic social service organizations, confirms Cainkar's observations. Similarly, Karim (2009), through a comparative ethnography of South Asian and African American Muslim interactions in Chicago and Atlanta, shows the integrative and transcending effect of an emerging transethnic Islamic solidarity rooted in what she calls "ummah ideals." Numrich (2012), Grewal (2014), 
Numrich and Wedam (2015), and Khabeer (2016) similarly describe the development of a distinctive interethnic, intersectional, contested, and dynamic conception of umma among Muslim Americans. From a different angle, Naber (2012) explores the coalescence of progressive Muslim and secular-leftist groups within Arab American activist circles in the San Francisco Bay Area. Shared concerns for social justice, anti-imperialism, and resisting patriarchal authority bring these quite different trajectories into intersection.

The combined evidence from these studies seems conclusive: a shift toward Islam among Chicago's Palestinians as well as among other Arab American and Muslim-majority immigrant communities has definitely occurred and is part of a transethnic phenomenon that conceives of a transnational Islamic community or umma inclusive of a wide range of ethnicities (Numrich 2012; Numrich and Wedam 2015). Moreover, Chicago and the United States as a whole seem, generally, to be but one instance of a global pattern. European Muslims, for example, appear to be developing a sense of an "Islamic diaspora" within the transnational framework of the European Union. Anchoring this growing self-perception are new Muslim organizations that transcend ethnic and national boundaries. This organization-building reflects the desire of ostensibly secular European states to define an "official" Islam that legally situates Muslims as Muslims. It also responds to the needs of European Muslims to advocate and defend Islam as legitimately European (Amghar, Boubekeur, and Emerson 2007; Sniderman and Hagendoorn 2007; Roy 2004; Kastoryano 2002; Saint-Blancat 2002, 2004; Mandaville 2001).

\section{Understanding the Religious Turn: Bringing Contingency and the Secular Back In}

Yet, as obvious as it may seem that an Islamic turn has occurred and that this turn is the result of global processes, several problems arise from the privileging of religion, Islam especially, and of transnationalism above all other possible analytical lenses. Specifically, the privileging of Islam as an interpretive category and the corresponding appeal to transnational religious networks and solidarities tend to elide the social, political, and historical complexities of the communities in which Islam is but one aspect of collective life. The consequence of this elision has been an obscuring of the contingency of Islam as a shaping force within individual lives. When the focus shifts to specific communities-their constituting narratives, key historical transitions, ideological cleavages, class, gender, and generational differences, and ethnic and religious distinctions-Islam, and religion generally, cease to be an all-embracing explanation. Instead, they become a contingent and internally complex element within a broader social field (Lybarger 2014).

The data and analyses I present in this book emphasize this contingency. They do so by focusing on how the immediate social contexts within which people live out their lives - the internal social processes of diaspora communities-shape individual outlooks and responses to the world. This focus on the positive, constructive 
dimension of subjectivity formation departs from other interpretations of the Islamic religious shift in Chicago. These other interpretations have emphasized, not incorrectly, the effect of external forces such as majoritarian racist reaction acting against the immigrant community. Cainkar (2004) has argued, for example, that the Islamic revitalization among Palestinian Arab Muslims in Chicago has more to do with experiences that resemble those of African Americans than it does with any other factor. Like African Americans, Arabs and Muslims (including African American Muslims) have been targets of negative stereotypes, discrimination, dehumanization, political exclusion, and voicelessness: "[ $\mathrm{t}]$ heir youth experience alienation in the schools and have to combat self-hatred imbued by textbooks, Halloween costumes, video games, talk shows and movies that portray them as barbaric" (117). Islam counters these experiences by providing dignity, identity, and strength (113).

But is racism necessarily the sole or even most important reason for the religious turn, especially among Palestinians? Racism is certainly a factor in the experiences of the individuals whose voices register in this book. The wider society has thrust the labels of "terrorist" and "Muslim" upon them as primary, pejorative identifications. Some have responded by retreating from or purposefully masking or discarding stereotypical signs of Muslimness. Many others have embraced the imposed identity, transforming it into a positive form of self-assertion. Some women, for example, explain that they wear hijab in part to proclaim their Islamic identity over and against the racist reaction. The argument emphasizing external, majoritarian pressure does have merit.

But bigotry alone does not explain why someone would necessarily embrace religious piety in response. Other nonreligious responses are possible; and even if the response is religious, that response can take a variety of forms. Why does someone choose a particular path, religious or secular? Arriving at an answer to this question requires a close look at how organizations, institutions, events, spatial processes, and generational, class, and gender dynamics positively shape a religious or secular disposition at the individual level, irrespective of majoritarian pressures.

Close empirical analysis of this sort is necessary because identities do not form purely as organic wholes in isolation. The Islamizing shift in Chicago is not an inexorable, single-track process of awakening. It is not a retrieval of some complete and unconditioned thing forgotten, for example, by a supposedly ignorant older generation too focused on assimilation. ${ }^{11}$ It is also not necessarily a response to racism in every case. Rather, it is an indeterminate phenomenon subject to specific historical conditions and to the shaping effects of diverse, overlapping institutional settings and milieus. Religious, nonreligious, and hybrid alignments in this process unfold in new ways and in multiple directions as individuals negotiate their identities within and across different social spheres. These negotiations reshape the alignments as individuals adapt to or make compromises with competing expectations for behavior. 
These points gesture back to a core question outlined at the outset of this chapter: what are the identity effects that result from crossings between social spheres and from the realignments to which they give rise? Specifically, what are the implications for secular and religious identities as they interact? The chapters ahead offer the following, multilayered answer. First, rather than disappearing as a result of the religious shift, secularism has instead persisted in revised or entirely new forms. Traditional secular nationalism continues even if its institutional frameworks have weakened. New, deinstitutionalized secularities have also appeared, often in reaction against the new piety, which, in its own right, has evolved along divergent axes in its interactions with secularism and secular spaces. A range of hybrid forms of identity that blend secularity and religiosity have emerged, as well. Secularism and religion are contingent and dynamic orientations. Their intersection and interaction generate a range of identity transformations.

\section{KEY CONCEPTS: IDENTITY, SECULARISM, AND RELIGION}

\section{Identity}

I have already repeatedly invoked the terms "identity," "secularism," and "religion" in this discussion. These terms and several others that inform the assertions and analyses in the rest of this book require specification. By "identity" I mean an emergent sense of self and other that forms and evolves narratively as "stories so far" (Massey 2005, 130) across five intersecting axes: epochal-historical; autobiographical; generational; structural; and spatial. The epochal-historical axis unfolds diachronically in relation to destabilizing, large-scale crises (for example, wars, environmental catastrophes, epidemics, mass displacements, economic depressions, revolutions and uprisings, violent state repression, vigilante violence directed at specific groups). These events create a shared experience, a shared sense of fate-memorialized in collective narratives, commemorative practices, and symbolic expressions-that become the common reference point for a generational cohort. Members of this cohort interpret subsequent events in relation to this formational crisis.

The process through which a sociohistorical generation comes into existence also entails the biological life cycle (birth, maturation, death). The life cycle facilitates a process of collective forgetting as new cohorts come to maturity under different historical conditions. ${ }^{12}$ New cohorts do not share in the same direct way the historical memories of earlier cohorts. The historical references shift, thereby enabling a relinquishing or, more accurately, a reinterpreting of past traumas.

At the same time, however, social structures like the family, schools, religious institutions, political movements and parties, and associations of all kinds serve to instill intergenerational continuity, thus mitigating the memory-eroding effects of the life cycle. These institutional contexts constitute a range of self-referencing 
practices, symbols, and narratives that individuals engage and absorb through participation within these settings. Such institutions are essential to sustaining memory and social coherence across time and space. Traumatic, epochal events, however, can sever this continuity by undermining received understandings of the world and generating a search for alternative interpretive frames, narratives, institutions, practices, and symbols. New movements and associations articulating a revised interpretation of the past and present can arise in these circumstances to draw into their ranks individuals just forming or consolidating their historical and political awareness (typically between the ages of fifteen and thirty). The wars of 1948 and 1967, the Israeli invasion of Lebanon in 1982, and the First Intifada of 1987-93 were events of this sort. ${ }^{13}$ In each case, new historical generations formed in tandem with new movements and parties as a consequence of the ensuing collective political crisis. The events marked each cohort in ways that distinguished it from other prior or succeeding cohorts.

Generational cohorts typically integrate individuals from across class, gender, religious, regional, and other salient distinctions. Palestinians who were in their late teens and twenties during the First Intifada of the late 1980s and early 1990s, for example, share a sense of a common generational location across their multiple lines of difference by virtue of having undergone this historical event together. Nevertheless, this same cohort splits internally in relation to competing interpretations of the significance of that shared experience. The most profound and enduring divide has been the one that has expressed itself in the Islamistsecular-nationalist cleavage. Such splits that result in opposing formations constitute synchronic "generational units" (Mannheim 1952, 304). These units express competing narratives about the shared epochal experience. The narratives form within contrasting, at times overlapping, sociopolitical spaces. Families, voluntary associations, religious organizations, political parties, student organizations, labor organizations, and a range of other social formations structure these spaces, institutionalizing the competing narratives of the contrasting generational units. These same institutional sites can also become divided as generational units vie to define and control them. In Palestine, secular nationalists and Islamists have fought for dominance, for example, on university campuses, within labor unions, and in associations like the Red Crescent Society (an equivalent to the International Committee of the Red Cross).

Individuals move into and out of these contentious zones. As they do so, they negotiate and integrate conflicting meanings into their own unique narratives, their own autobiographical accounts. These accounts may or may not track consistently with the social and political movements and spaces through which the contrasting generational units form. These convergences and discrepancies between the autobiographical and the generational indicate the fluidity and contingency of identity at different levels of aggregation, from the individual to the 
collective. The analyses in this book bring such complexities to the fore. They focus primarily on individual accounts but in doing so trace the effects of broad processes such as the generational. The individual experience as conveyed through the telling of a life story in an interview becomes a portal to collective experience, but one that reveals tensions and digressions and transgressions of dominant narratives and practices in often unexpected ways (Riessman 2008, 1-19).

The fluidity of autobiographical and generational processes in relation to diverse institutional sites is consistent with how geographers conceive of space as an emergent phenomenon. Space is "the dimension of multiple trajectories, a simultaneity of stories-so-far [ . . it is] the multiplicity of duration" (Massey 2005, 24). This idea implies not only that time-space has a narrated quality but also that it is indeterminate. Social spaces, and the identities that form within them, are, on this account, sites of open-ended narrative intersection. Space is a "coexisting heterogeneity," a "contemporaneous plurality" that is "always in the process of being made" - "it is never finished, never closed" — through these intersections (9). ${ }^{14}$

Space, in other words, refers to a range of co-occurring, ever forming and re-forming narrative arcs in any given moment and context. Space is not a twodimensional reality external to the narratives we create and re-create and inhabit and abandon but rather a meaningful context constituted through our storytelling. Chicago's "South Side," for example, emerges as a place through the accounts that give it form and significance. These narratives are diverse in their trajectories and in their intersections or lack thereof. There is more than one South Side.

The emergent senses of self that constitute identity in any given site or place are the result of such narrative intersections and disconnections. This narrative process is generational, epochal, institutional, autobiographical, and spatial all at once. Moreover, the fluidity between diaspora spaces like Chicago and homeland spaces like the West Bank means that identity trajectories can imbricate: the Intifada generational cohort forms within and across both spaces, for example. This coinciding of space means that the sociomoral orientations carried within the constitutive narratives can also overlap. These orientations constitute milieus that integrate individuals structurally across class, race, religion, gender, generation, and, because of the coinciding of space, even region (Palestine and the United States, for example). ${ }^{15}$

At the same time, however, diaspora spaces generate their own variants of these milieus and trajectories. They undergo their own epochal events, produce their own distinct institutions, and generate their own narratives. As a result, they constitute a unique range of actual and possible trajectories. The events of September 11, 2001, have a particular salience that defines the U.S. diaspora space, for example. They have different defining effects in the homeland space of Palestine.

The key point, however, is that "diaspora" and "homeland" as meaningful, narrated contexts can and do intersect and overlap. Through migration, Palestine 
crosses with Chicago, giving rise intergenerationally and interspatially to the distinct place "Palestinian Chicago." Chicago, too, is interspatial within itself: multiple imbricating, intersecting spaces constitute it. This phenomenon additionally shapes the space of Palestinian Chicago in distinct ways that diverge from the interspatial dynamics in Palestine itself.

\section{Spatial Dynamics and Identity Formation in Palestinian Chicago}

Chicago, as a multisited diaspora space, has shaped the Palestinian identity dynamics that are the focus of this book in four principal ways. First, it has brought Palestinian immigrants into interaction with a wide diversity of other groups. This interaction has had a range of consequences. Black-Palestinian relationships on the city's South Side, for example, have produced conflicted economic relations. As chapter 1 shows, Palestinians have historically related to African American communities in the role of petty shopkeepers working on the edges of the segregated and impoverished black residential zones. During the 1960s and 1970s, however, new forms of relationship, new narrative intersections, developed as Palestinian political activists inspired by Third World anti-colonialism forged solidarity connections with the Black Panther Party and Black Power movements in the city and elsewhere nationally (Fischbach 2019; Feldman 2015; Pennock 2017).

Recently, these relationships have undergone renewal in the aftermath of the police killings of African Americans and the rise of the Black Lives Matter (BLM) movement (Erakat 2018). In 2014, for example, Palestinian activists from Chicago traveled to Ferguson, Missouri, site of the killing of Michael Brown, whose death at the hands of police sparked BLM's formation, to demonstrate black-Palestinian solidarity. Since then, in Chicago, young Palestinian activists, working principally through the AAAN, have collaborated with BLM chapters to address police violence and police surveillance of black and Arab communities. These past and current interactions have shaped Palestinians culturally and politically, most explicitly in the embrace among some youth of a "black" identity. This identity alignment has occurred through the encounter with black liberation politics, hiphop, and Black Islam. Conversely, Palestine and the Boycott, Divestment, and Sanctions movement have come to serve as important symbols for a countercultural resistance identity across racial and ethnic lines. Within transnational activist networks Palestine has emerged as a rallying symbol in the effort to counter "the post-9/11 consolidation of the US-Israeli state alliance" (Collins 2011, 7-8; see also Tawil-Souri 2016, 15-28). These networks include Muslim organizational spaces and milieus, in which, as noted above, Palestine and Jerusalem, specifically, serve metaphorically to orient a cross-ethnic Islamic solidarity.

A second way in which the diaspora context of Chicago has shaped Palestinian identities in complex ways has been through socioeconomic class. Since the late 198 os, in conjunction with the Islamic shift, Palestinian immigrants in the city have transitioned in large numbers to the near southwest suburbs. This shift has 
occurred as part of a process of wealth accumulation among small business owners in the older urban enclave on the city's Southwest Side. The pattern of suburban shift is not unique to Palestinians. As the next chapter shows, it replicates the movements of other groups, including white ethnic communities that left the city as part of "white flight" - an exceedingly complex process, as the next chapter will illustrate-during the 1950 s and 196os. The Palestinians who speak in this book refer to their own transition to the suburbs, in fact, as a version of "white flight," thereby underlining the race and class dimensions of the phenomenon. Their reasons for invoking this term include the desire of their families, as they report, to escape gang violence and to improve their socioeconomic position and status. Scholars have often referred to this process as "becoming white" or as assimilation pivoting on a rejection of blackness (Gualtieri 2009; Roediger 2006). The desire to be categorized as white, or at least as not black, has a long history linking back to the racial categories that once determined eligibility for citizenship. Early Arab immigrants ("Syrians") fought successfully in the courts to be defined as "white," and Arab Americans to this day continue to be classified as such in the US census (Gualtieri 2009). Socially and culturally, however, the status of Arabs in the United States has remained ambiguous: US support for Israel since 1948 and the enduring perception of Muslim and Arab immigrants as a malevolent "enemy within" have repeatedly placed the Arab American, and now Muslim American, presence and claim to citizenship under suspicion (Cainkar 2009).

The Palestinian suburban transition has reconfigured the interstitial position of Palestinians in the city: it shifts their location to the near southwestern suburbs that separate white suburbia from the predominantly black and brown South Side urban space. This process points to the distinct role of the city as a mechanism of identity formation. As an intensely diverse yet also violently segregated space, the Chicago metropolitan area is a site of multiple, intersecting race, class, ethnic, and religious identity trajectories. These trajectories unfold spatially in ways that reinforce but also destabilize community cohesion. Immigrant enclaves form within the context of racial divisions that are spatially instantiated. The locations of these enclaves can shift, as the Palestinian suburban transition illustrates, but they can also become undone as individuals challenge the institutional mechanisms that instill and reinforce enclave solidarity and identity. Religion facilitates both processes. The establishment of well-endowed organizations like the Mosque Foundation in the southwest suburb of Bridgeview, for example, generates strong enclave solidarities and a new Islamic identity that parallels the Islamic revival in Palestine and elsewhere in the Middle East. Churches have played a similar boundary-marking role in Palestinian Christian communities, with Christian solidarity responding to the new Islamization in the suburbs. At the same time, however, Islam has provided an alternative context for a countercultural identity, as described above: Black Islam, especially, constitutes the space of this possibility (Khabeer 2016). The city's spatial multiplicity also opens up alternatives for 
individuals to break entirely with enclave solidarity and to reject or significantly reconfigure religious and national identities. Artistic milieus, youth party scenes, activist organizational spaces, and universities situated elsewhere in the city are primary mechanisms for this process.

A third complicating factor in diaspora identities is the experience of living between the shatat (diaspora) and the iblad (Palestinian Arabic colloquial for "homeland," that is, Palestine). As chapter 1 shows, since their first arrival in the city, Palestinian immigrants in Chicago have maintained familial and economic networks that tie them to "back home." Early immigrants, who were predominantly men, returned to their villages and towns to repatriate their earnings and to get married. They then travelled back to Chicago to work for years at a time, before again returning to their home communities.

After the wars of 1948 and 1967, these patterns changed as these men brought their families to the United States with them. New family reunification provisions in US immigration law allowed extended family to migrate at this point. Still, as the ethnographic analyses in the chapters to follow will show, families continued to maintain links with communities in Palestine. A common practice has been for parents and children to spend summers or even entire school years in Palestine to reinforce Arabic language abilities, attachment to Palestinian society and culture, including religion, and connections with relatives (Abu El-Haj 2015). This practice, in fact, dates to the earliest periods of family settlement in Chicago (al-Tahir 1952). It has resulted in an intergenerational bifocality that provides contrasting lenses through which to view and make sense of lived realities. This bifocality blurs differences between the experiences of recent arrivals and long-established immigrants. ${ }^{16}$ To be a Palestinian immigrant in Chicago, regardless of generational location, often means to live across homeland and exile and thus to develop dual lenses through which to perceive space and place. This perceptual duality is facilitated as much by social media as by actual, in-person travel between the shatat and the iblad.

Gender dynamics constitute a fourth factor in diaspora identity formation. The religious shift, Islamic and Christian, has reinforced patriarchal order within the emerging Palestinian immigrant middle classes in the suburbs. ${ }^{17}$ In doing so, it has articulated a type of gendered "respectability" that shores up enclave identity against social currents that challenge the patriarchal ethos and the gender and sexual identity norms that underlie it. Here, too, the city, as a site of multiple, overlapping spaces marked by diverging, gendered value orientations provides the opportunity for individuals to contest the patriarchalization of the enclave. Several individuals profiled in this book stake out oppositional stances from standpoints they embrace in other spheres, such as universities and domestic abuse shelters, where they develop critiques of gendered hierarchies.

At the same time, however, other individuals embrace the Islamic turn as part of a different kind of challenge to patriarchal order. Here, too, encounter with student 
groups like MSA chapters at universities provides the opportunity for learning and deploying an anti-patriarchal reading of religious texts against patriarchal norms in the home. Thus, even if the religious shift documented in this book has redefined what it means to see oneself as Palestinian, it has done so in tension with a range of other identity possibilities that flow not only from the traditions of secular nationalism that predate the Islamic shift but also from interactions across the class, race, shatat/iblad, gender, and spatial-socio-moral divides in cities like Chicago.

\section{Secularism and Religion}

The ethnographic descriptions in this book focus on identity transformations stemming from the religious shift and the deinstitutionalization, not the disappearance, of secularism. I have already discussed these two terms-religious and secular-in relation to the history of Palestinian Islamism and Palestinian secular nationalism. The terms require elaboration, however, at a general analytical level. As invoked in this book, "secular" and "religious" and "secularism" and "religion" constitute ideal-types. Drawn from empirical data, ideal-types deliberately accentuate certain features of "patterned meaningful action" that in lived reality is fluid and complex (Kalberg 2012, 99-101). The ideal-type as such does not exist, empirically. Rather, it is a provisional abstraction that enables the demarcation, comparison, and interpretation of phenomena one wishes to understand. ${ }^{18}$ Inevitably, through application, this abstraction, the type in its pure form, will undergo revision. Instead of a single, undifferentiated image of secularism, for example, the result of application will be an empirically rich concept reflecting different developmental possibilities, including hybrid ones influenced by the interaction with religion.

Ideal-typically, then, in this book, "secularism," in its pure form, encompasses any social orientation, practice, mode of solidarity, or stance that implicitly or explicitly resists, rejects, demotes, ignores, or otherwise suspends, momentarily or permanently, the prior claim of religious authority. ${ }^{19}$ Secularist stances manifest empirically in a range of forms. What makes an orientation or stance or mode of response in the end "secular," however, is the explicit rejection, implicit irrelevance to it, or suspension of the primacy of particular religious authority above all other considerations as a foundation for shared ethics and social and political identification. For example, secular nationalism in the Palestinian context is secular to the extent it privileges national identity and belonging above specific sectarian religious solidarities. Positively, secularism can embrace a range of value orientations, including pluralism, tolerance, individual liberty, and the like. Empirically, it can blend with religious orientations. It is possible, for example, to adhere to a religion while also adopting a secular-but not necessarily secularist-stance in social or political spheres beyond the specific religious community. Doing so entails a strategic suspending or an interpretive recasting of the priority of religious solidarity. 
Similarly, secularist positions can soften to include religious solidarities through similar kinds of operations that relax the exclusion of the religious. How this occurs in Palestinian diaspora situations will be the focus of the chapters ahead.

"Religion," in contrast with "secularism," refers to institutions and practices that, in their implicit logic, presume the existence, power, and authority of superhuman forces and the capacity to interact with and gain access to these forces for the purpose of preventing or mitigating and ending crises occurring in the body, nature, and society (Riesebrodt 2010). ${ }^{20}$ Religious solidarity is an implicit requirement for ensuring access to these powers. Religious specialists often explain human sufferings and failures in terms of an absence of religious solidarity and commitment. These explanations are theodicies-justifications for the existence of suffering (evil) despite the presence of an omnipotent and omniscient God who presumably provides protection in exchange for honor (expressed in worship) and obedience (expressed in adherence to divinely given mandates). Religious theodicies can become politically salient in periods of prolonged conflict and national crisis. The success of Hamas demonstrates how this can occur in the Palestinian context. Under such conditions, religions can reorient the social and political fields.

\section{Hybridity and Syncretic Secularity}

As I show in this book, secularism and religion constitute possible stances that individuals can adopt toward their lived conditions. A range of factors-for example, ethnicity/race, class, gender, and generation-interrelate with and shape these contrasting stances in various ways. Hybrid positions are possible. My use of "hybrid" departs from postcolonial and postmodernist conceptions of the term. In postcolonial literature, hybridity features typically in arguments about how the subaltern's subjectivity is not simply the consequence of the imposition of hegemonic colonialist discourses. Rather, the subaltern selectively appropriates and reinterprets hegemonic discourses to produce a hybrid consciousness and knowledge. Colonial discourse, too, reveals the impact of this transformative reception when analyzed critically (Bhabha 1994).

By contrast, in my broader use of the term, hybridity is less a sign and consequence of colonial power imbalances than a description of what happens to religious and secular orientations through the crossing of social circles. With Simmel and Weber, I conceive of modern societies as comprising multiple institutional spaces and sociomoral milieus. As individuals cross into and out of these various spaces, they encounter contradictions and tensions that challenge their value orientations (Simmel 1955 [1922]). One consequence of this experience is the development of reflexivity within the individual that can then lead into a process of autobiographical revision and moral reorientation. This process can entail a selective adaptation and integration - a hybridization - of orientations that serve to resolve the tensions, or "cross pressures" (Taylor 2007), which individuals can experience in negotiating moral contradictions across different social and 
institutional contexts. When the hybridization involves religious-secular intersection, the result is a "syncretic secularity" (Eipper 2011, and see also chapters 5 and 6 in this book).

My engagement with questions of hybridity, syncretic formations, and interaction within and across secular and religious spaces departs from much of the current debate about secularism. This debate concerns itself primarily with the modern state and with a general political logic of secularism that uniformly defines and regulates the space of the religious and the secular across different national contexts (e.g., Asad 1993, 2003; Mahmood 2005, 2006, 2010, 2016; Sullivan, Hurd, and Mahmood 2015). The problem in some of these analyses lies in the tendency to view secularism and the modern state in monolithic terms despite variations in the social and political fields from one national context to another (Joppke 2017). By contrast, I view the state as internally complex: its various bureaucratic structures interact, often at cross purposes, with diverse nonstate institutions (including religious ones), class and generation formations, social and political movements, and cultural enclaves and milieus that exist independently within a wider field of political and social tension. The field of tension can take many forms in relation to diverging national settings. Within and across these fields, secular and religious discourses, practices, and institutions can develop in multiple, indeterminate directions and in doing so give rise to a range of subjectivities, including hybrid ones.

The data I analyze, in particular, provide a detailed demonstration of the key point that "the religious and the secular exist $[\ldots]$ in a continuing dialectic that engender[s] any number of transformations" (Martin 2014, 16; see also Riesebrodt 2014). In fact, the interactions generate dynamic, synthetic forms, making it difficult to maintain the distinction between secular and religious: even if the distinction is useful for analytical purposes it nevertheless becomes a fluid line within lived realities. Palestinians have participated in this indeterminate, interactive process, just as have every other group in the West and globally. Consequently, Palestinian experience offers perspective on the diverse range of what Mahmood (2010, 295) terms "conceptions of the self, agency, and accountability that modern secularism makes possible [and] which link 'us' and 'them' indelibly (if messily) across putatively civilizational divides." ${ }^{21}$ Mahmood has primarily political secularism-secularism as state policy-in mind, whereas my ideal-typical elaboration of the term focuses on secularism as a particular kind of individual subjectivity or agency, that is, as a "conception of self" as it is articulated and practiced by particular groups and individuals arrayed across the class, gender, generational, religious, racial, political, and spatial spectrums. These self-conceptions may or may not track with the secularizing policies and secularist political values of any given state, society, or milieu. Thus, what emerges is a multiplicity of ways to express and enact secularity. There are multiple secularisms and secularities, not a simple "modern secularism." 
Much of the prevailing discussion of Palestinian and Arab and Muslim immigrants disregards this sort of fluidity that the conceptual frames I have just elaborated attempt to bring into focus. This disregard comes at a cost to understanding. When they merit attention, Palestinians and Arabs and Muslims, generally, often serve as targets of polemical caricature rather than as subjects of an informed inquiry that can elucidate questions of religion, migration, identity, and belonging. The reductive portrayal can have a parallel within Palestinian communities: the priority of representing the nation against its negation often leaves little if any latitude for individual expression. The diaspora, however, offers spaces beyond the nation and its enclaves, and some individuals seek it out to forge alternative futures.

\section{ORGANIZATION OF THE BOOK}

Chapter 1 examines the formation and historical location of Palestinian Chicago in relation to the wider history of immigration and the divisions of race and class in the city. A main concern is to show the ambivalence of the Palestinian location. Palestinians are strangers in Simmel's sense, mediating across racial lines but never fully integrating as members of the wider urban community. This status changed following the wars of 1948 and 1967 as Palestinians for the first time began to orient themselves toward permanent residency in their Chicago exile and in doing so created identifiable enclaves. The centers of these enclaves have shifted in ethos from secular-nationalist to religious-Islamic and Christian-in an arc paralleling the rise and decline of the Palestine Liberation Organization (PLO) as the diaspora's preeminent institution.

Chapter 2 shifts the focus from historical background to the ethnographic present with an analysis of the secular milieu. The chapter opens with a vivid interview with one of the founders of the Arab Community Center (the markaz). Steeped in pan-Arabism, this individual decries the Islamic shift in the immigrant community. The chapter continues with a generational analysis of the changes in secular subjectivities. This analysis demonstrates how the religious turn shapes secularism across historical generations.

Next, chapter 3 pivots to examine the Islamic shift through observations of two events that American Muslims for Palestine (AMP) held in 2013 and 2014, respectively. AMP is a prominent organization. It holds an annual conference on Palestine that draws thousands of participants from the Chicago metropolitan area and across the United States; and it has recently established a national advocacy office in Washington, DC. What AMP does in the Chicago community is thus representative of a wider transformation that has fused Islam with Palestinian nationalism in the diaspora.

Chapter 4 continues the focus on the religious shift, both Islamic and Christian, by examining individual subjectivity across the generational continuum. The data 
for this discussion derive from in-depth life history interviews with immigrants who either established or inherited the core institutions of the religious turn in its Islamic and Christian forms. Individuals for whom the wars of 1948 and 1967 were formative of their generational outlook detail key shaping experiences in Palestine and then describe the arc from that past to the realities they face in the Chicago immigrant context. This generation created the institutional foundations of the subsequent religious shift. The narratives of individuals from succeeding generations show how the earlier religious institutionalization channels their formative historical experience. This experience encompasses the First and Second Intifadas; the Oslo Peace process; the concomitant withering of the PLO as the dominant organizational structure of the diaspora; the September 11 attacks; and the subsequent intensification of the racist exclusion and law-enforcement surveillance that have persistently undermined Arab and Muslim sense of belonging in the United States. I analyze Muslim and Christian narratives, showing a mirroring of Islamic and Christian sectarian enclavization in this process of religious turning. The religious turn has the consequence of shrinking secular, nonsectarian space within which Palestinians might interact and form shared political solidarities across their confessional boundaries.

Chapters 5 and 6 continue the analysis of fieldwork data but shift the focus to the intersections of religious and secular subjectivities. The chapters elaborate the concept of "syncretic secularity" (Eipper 2011), which captures the hybridizing potential of secular and religious interactions. The analysis of case profiles in these chapters illustrates and further develops the concept by describing two main syncretic trajectories: religious secularity and secular religiosity. Religious secularity originates in the secular milieu but then arcs toward the religious; conversely, secular religiosity moves from the religious-sectarian context to the secular. Religious secularity manifests, in my data, in three subforms: reversion, conversion, and accommodation. Secular religiosity, which I describe as "rebellion" against the religious shift, can lead either to atheism or to spiritualization. Chapters 5 and 6 explain and demonstrate these sub-types in detail and examine how race, class, gender, and generation shape their development. The analyses also show that individuals can shift along the syncretic range within their own particular life trajectories. The profiles thereby illustrate not only the different types of syncretic orientation but also the fluidity that can manifest within a single autobiographical account.

The conclusion returns to the major themes of the book, principally the secular-religious interaction and its transformational effects on Palestinian identity in US exile. The current moment is a time of deep and continuing secular nationalist and Islamist political division in Palestine. Palestinians, especially through new global campaigns such as the Boycott, Divestment, and Sanctions movement, seek to re-envision politics beyond the secular-religious binary that has defined the competition between Hamas and Fatah, primarily, in the Occupied 
Gaza Strip and West Bank. The binary nevertheless persists and, in diaspora communities like Chicago, produces new trajectories of identity. If there is one lesson to draw from this book it is that religion shapes Palestinian immigrant identities in infinitely complex ways. Moreover, religion is not the only conditioning force. Secularism also is an important identity framework. Even if it has appeared to be in decline, institutionally, secularism and secularity remain nevertheless relevant to the new forms of orientation that this book analyzes. Still, the individuals whose narratives are at the center of this book do not fall easily on one side or the other of the binary. The new understandings emerging in Chicago-at least among my interlocutors-of what it means to see oneself as Palestinian exceed the divisions of religious and secular, Muslim and Christian, Palestine and the United States. In doing so, they reveal the rich complexities and possibilities of Palestinian identities in and beyond the exile. 